\title{
Pengurangan Resiko Bencana Berbasis Komunitas Melalui Pembentukan Desa Tangguh Bencana di Kabupaten Pidie Jaya Nanggroe Aceh Darussalam
}

\section{Muzakir Zainal}

Program Studi Teknik Geofisika

Fakultas Teknik, Universitas Syiah Kuala

E-Mail: muzakirzainal@unsyiah.ac.id

\section{Muhammad Yanis}

Program Studi Teknik Geofisika

Fakultas Teknik, Universitas Syiah Kuala

E-mail: yanis@unsyiah.ac.id

\section{Marwan}

Program Studi Teknik Geofisika

Fakultas Teknik, Universitas Syiah Kuala

E-mail: marwan.geo@unsyiah.ac.id

\section{Article History:}

Received: 2019-12-15

Revised: 2020-04-17

Accepted: 2020-05-31
Keywords: Desa Tangguh Bencana, Disaster Risk Reduction, Disaster Mitigation, Participatory Rural Appraisal

\begin{abstract}
Aceh province is traversed by the Sumatran fault which stretches for $1900 \mathrm{~km}$ from the southern tip of Sumatra Island to the Andaman Sea. Seismic activity along this active fault line poses a serious threat to Aceh including in Pidie Jaya Regency. This community assistanc formulated a program called Desa Tangguh Bencana (DESTANA) to optimize the active role of the community by evaluating Participatory Rural Appraisal (PRA). The target was rural communities with diverse educational and economic backgrounds. The activity was carried out by: providing information on disaster awareness, providing assistance to village governments to formulate village regulations based on disaster risk agreements, and map making and installation of information boards for evacuation routes and path planning by considering local values in the village. The program resulted in the formation of a disaster risk team and a community group who were alert to ongoing disasters, as well as an increase the community's knowledge.
\end{abstract}

\section{Pendahuluan}

Provinsi Aceh merupakan wilayah dengan aktivitas tektonik yang sangat tinggi, hal ini disebabkan oleh keberadaan Great Sumatran Fault (GSF) yang membentang dari Lampung sampai dengan laut Andaman. ${ }^{1}$ Posisi ini menjadikan Aceh sebagai salah satu Provinsi dengan potensi bencana gempa bumi sangat tinggi. Gempa bumi pada tahun 2013 di Bener Meriah dan Tangse Pidie menjadi bukti bahwa Great Sumatran Fault

${ }^{1}$ Kerry Sieh and Danny Natawidjaja, "Neotectonics of the Sumatran Fault, Indonesia," Journal of Geophysical Research: Solid Earth 105, no. B12 (2000): 28295-28326. 
memiliki aktivitas tektonik yang tingggi. Sehingga sejumlah penelitian kebumian dari berbagai aspek ilmu hanya fokus pada bagian utama GSF. Muksin et al., 2019 berhasil memetakan distribusi gempa bumi disepanjang GSF, selain itu penelitian geomatika menunjukkan hal yang sama, berupa adanya pergerakan kerak bumi dalam kecepatan yang relatif kecil. ${ }^{2}$ Selain jalur patahan utama terdapat juga beberapa sesar sekunder akibat dari aktivitas geologi dari sesar utama, tetapi berdasarkan rekam jejak sejarah kegempaan di Aceh sesar tersebut belum pernah menunjukkan aktivitas sebelumnnya, namun pada 7 Desember 2016 sesar Samalanga-Sipopok menunjukkan aktivitas kegempaan dengan magnitude 6.5 S.R di daerah Pidie Jaya mengakibatkan 104 orang meninggal dunia, 139 orang luka berat, 718 orang luka ringan, serta 43.529 orang mengungsi.

Pada Gambar 1, menunjukkan kerusakan infrastruktur pasca terjadi gempa bumi di Kabupaten Pidie Jaya. Banyak korban yang timbul akibat bencana juga diperparah oleh minimnya pengetahuan masyarakat akan mitigasi bencana.$^{3}$

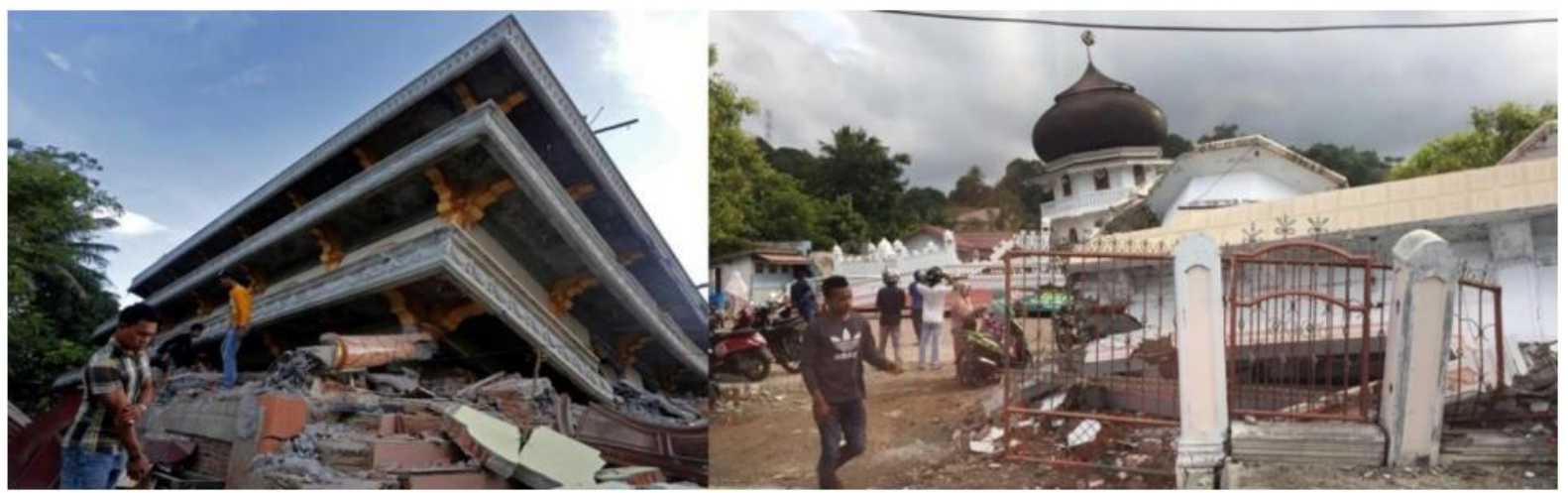

Gambar 1. Kondisi Pidie Jaya pasca terjadi gempa bumi dengan magnitude 6.5 S.R.

Kabupaten Pidie Jaya merupakan salah wilayah yang memiliki potensi bencana gempa bumi yang sangat tinggi, hal ini akibat keberadaan sesar Samalanga - Sipopok dan struktur geologi yang tersusun dari alluvium. ${ }^{4}$ Dengan demikian perlu dilakukan mitigasi bencana sebagai upaya mempersiapkan masyarakat yang sigab bencana di masa yang akan datang. Sehingga dapat hidup secara berdampingan dengan kondisi alam yang memiliki potensi bencana sangat besar.

Berdasarkan peraturan Menteri No 33 Tahun 2006 Tentang Mitigasi Bencana, ada beberapa faktor penting yang harus dilakukan dalam mitigasi bencana sebagai

2 Takeo Ito et al., "Isolating Along-strike Variations in the Depth Extent of Shallow Creep and Fault Locking on the Northern Great Sumatran Fault," Journal of Geophysical Research: Solid Earth 117, no. B6 (2012).

3 Siska Ayu Kartika, Agung Prabasworo, and Abdy Nugroho, "Sosialisasi Upaya Pencegahan Dan Penanggulangan Bahaya Kebakaran Di Sekolah Luar Biasa (SLB) Kota Balikpapan," Abdimas Universal 1, no. 2 (2019): 30-38.

4 J F Genrich et al., "Distribution of Slip at the Northern Sumatran Fault System," Journal of Geophysical Research: Solid Earth 105, no. B12 (2000): 28327-28341. 
upaya pengurangan risiko bencana, diantaranya pengumpulan informasi yang detail dan akurat terkait potensi bencana di suatu wilayah yang kemudian divisualkan dalam bentuk peta rawan bencana, sosialisasi sebagai upaya peningkatan pengetahuan masyarakat terkait potensi dan upaya pengurangan risiko bencana, membentuk kelompok masyarakat sigap bencana, dan merumuskan peraturan yang mengurangi risiko bencana.

Pengemabangan Desa Tangguh Bencana (DESTANA) merupakan solusi yang paling mudah untuk mengimplemenstasikan Peraturan Menteri No 33 Tahun 2006. Selain itu akan sangat membantu dalam meningkatkan peran aktif masyarakat dalam mitigasi bencana. Dimana selama ini upaya pengurangan risiko bencana hanya dilakukan oleh stakeholders terkait (Badan Penanggulangan Bencana Daerah) tidak melibatkan masyarakat secara teknis. Dengan demikian dilakukan suatu pendekatan dengan menggunakan metode Participatory Research Appraisal (PRA) untuk mengoptimalkan peran masyarakat desa sebagai subjek dalam pembentukan DESTANA. ${ }^{5}$

\section{Metode}

Pembentukan Desa Tangguh Bencana (DESTANA) dilakukan metode pendekatan yang berbasis pada Participatory Action Research dengan mengoptimalkan peran masyarakat dalam kegiatan mitigasi bencana sebagai upaya pengurangan risiko bencana. Ada beberapa tahapan dalam pembentukan DESTANA, diantaranya sebagai berikut; $^{6}$ (1) Sosialisasi mitigasi gempa bumi dilakukan dengan melibatkan peran mahasiswa sebagai agen bencana dengan sasaran utama terdiri dari perangkat desa, siswa sekolah dan masyarakat desa; (2) Pemasangan jalur evakuasi dilakukan secara bersama dengan masyarakat; (3) Pembuatan peta dilakukan secara bersama dengan masyarakat untuk mengumpulkan informasi terkait administrasi desa dan penetuan lokasi pemasangan papan informasi jalur evakuasi; (4) Pembentukan tim sigap bencana yang tertuang dalam perdes yang dirumuskan secara bersama dengan melibatkan seluruh elemen masyarakat; dan (5) survei tingkat pengetahuan masyarakat dilakukan sebelum dan sesudah pelaksanaan program sebagai upaya mengukur tingkat pengetahuan masyarakat terhadap bencana. Kemudian pembentukan Tim Sigap Bencana (TSB) dilakukan secara simbolis di kantor kecamatan dengan dilantik secara khusus oleh Camat Trienggadeng Kabupaten Pidie Jaya. Selain itu para tim pengurangan risiko bencana diberikan pembekalan secara langsung oleh staf ahli dibidang Desa Tangguh Bencana dari Badan Penanggulangan Risiko Bencana Daerah Provinsi Aceh.

5 Rina Suryani Oktari, “Peningkatan Kapasitas Desa Tangguh Bencana,” Jurnal Pengabdian kepada Masyarakat (Indonesian Journal of Community Engagement) 4, no. 2 (2019): 189-197.

${ }^{6}$ I Wayan Krisna Eka Putra and I Putu Gede Diatmika, "Rintisan Desa Tangguh Bencana (Destana) Di Desa Gitgit, Kecamatan Sukasada, Kabupaten Buleleng," Jurnal Ilmiah Ilmu Sosial 4, no. 2 (2018): 161166. 


\section{Hasil dan Diskusi}

\section{Sosialisasi Mitigasi Bencana}

Sosialisasi mitigasi bencana merupakan upaya awal yang dilakukan sebagai bentuk peningkatan pemahaman mitigasi bencana dan pengetahuan masyarakat terhadap potensi bencana yang ada disekitarnya. Kegiatan sosialisasi bencana dilakukan dengan melibatkan mahasiswa sebagai agen bencana untuk memberikan pemahaman kepada masyarakat. Target utama dalam kegiatan sosialisi adalah perangkat desa selaku pengambil kebijakan pemerintahan desa, siswa sekolah dasar dan masyarakat desa.

Kegiatan sosialisasi dilakukan dengan teknik yang berbeda-beda, untuk masyarakat biasa dilakukan secara menyeluruh dengan mendatangi setiap masyarakat di desa, terutama titik berkumpul warga (Gambar 2). Mahasiswa yang menyampaikan materi juga dibekali dengan modul mitigasi bancana untuk mempermudah dalam memberikan contoh bencana kepada masyarakat. Selain memberikan materi mahasiswa juga melakukan pendataan untuk mengumpulkan informasi mengenai dampak dari gempa bumi tahun 2016 yang terjadi di Kabupaten Pidie Jaya.

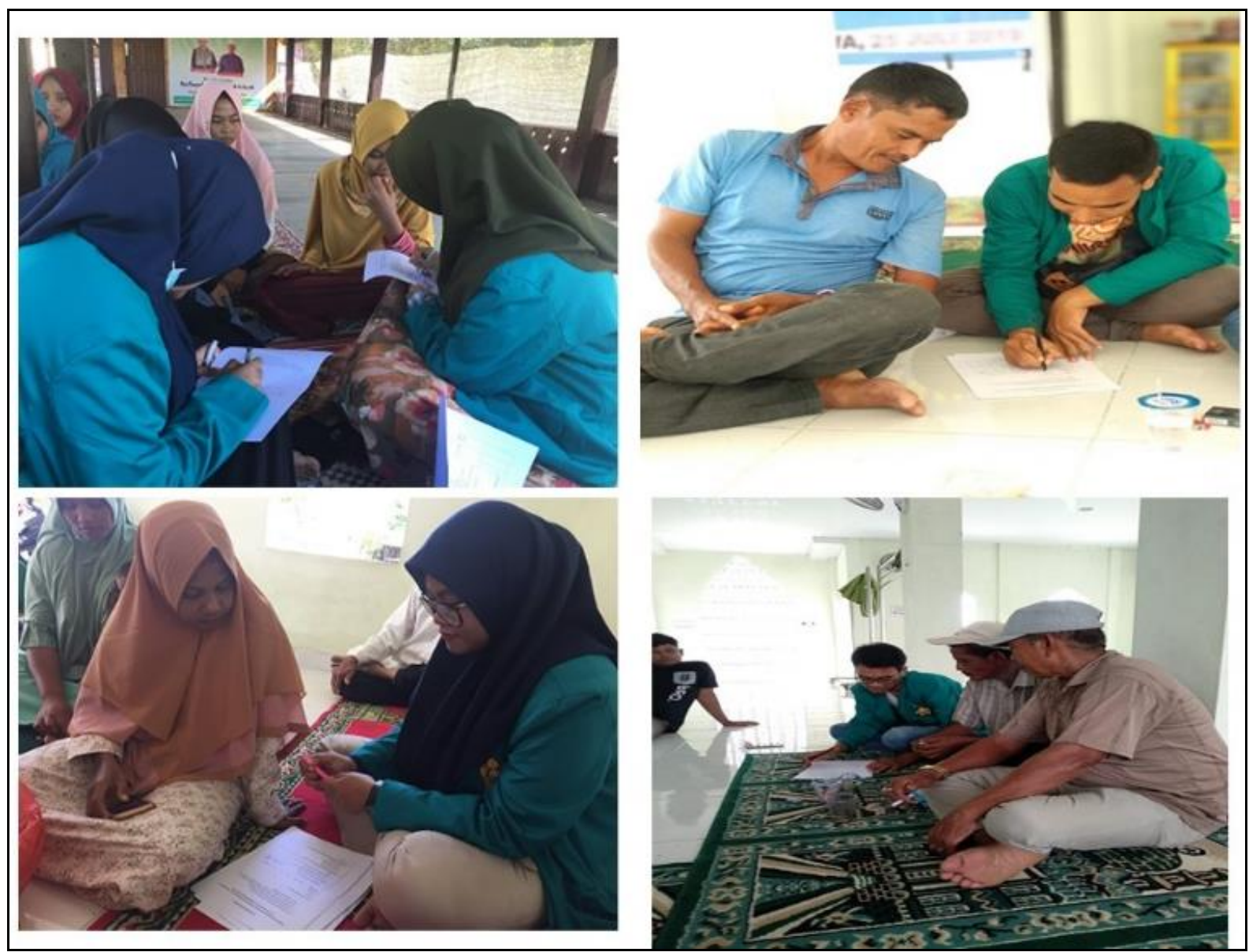

Gambar 2. Dokumentasi sosialisasi pengetahuan bencana kepada masyarakat 
Kegiatan sosialisasi tidak hanya dilakukan terhadap masyarakat biasa, tetapi juga kepada siswa Madrasah Ibtidaiyah Negeri 10 Pangwa Kecamatan Trienggadeng, Kabupate Pidie Jaya. Sosialisasi dilakukan dengan melibatkan peran guru secara aktif, untuk pendekatan yang dilakukan sangat menarik minat para siswa (Gambar 3). Dimana siswa diajak untuk menonton video Safety Briefing dan game kebencanaan yang menarik "Earth Game", selain itu pada akhir kegiatan sosialisasi dilakukan simulasi bencana gempa bumi. Kegiatan tersebut dilakukan dengan mengoptimalkan peran guru secara aktif,7 dengan harapan dapat dilakukan secara berkelanjutan untuk membentuk siswa yang sigap akan bencana di masa mendatang.

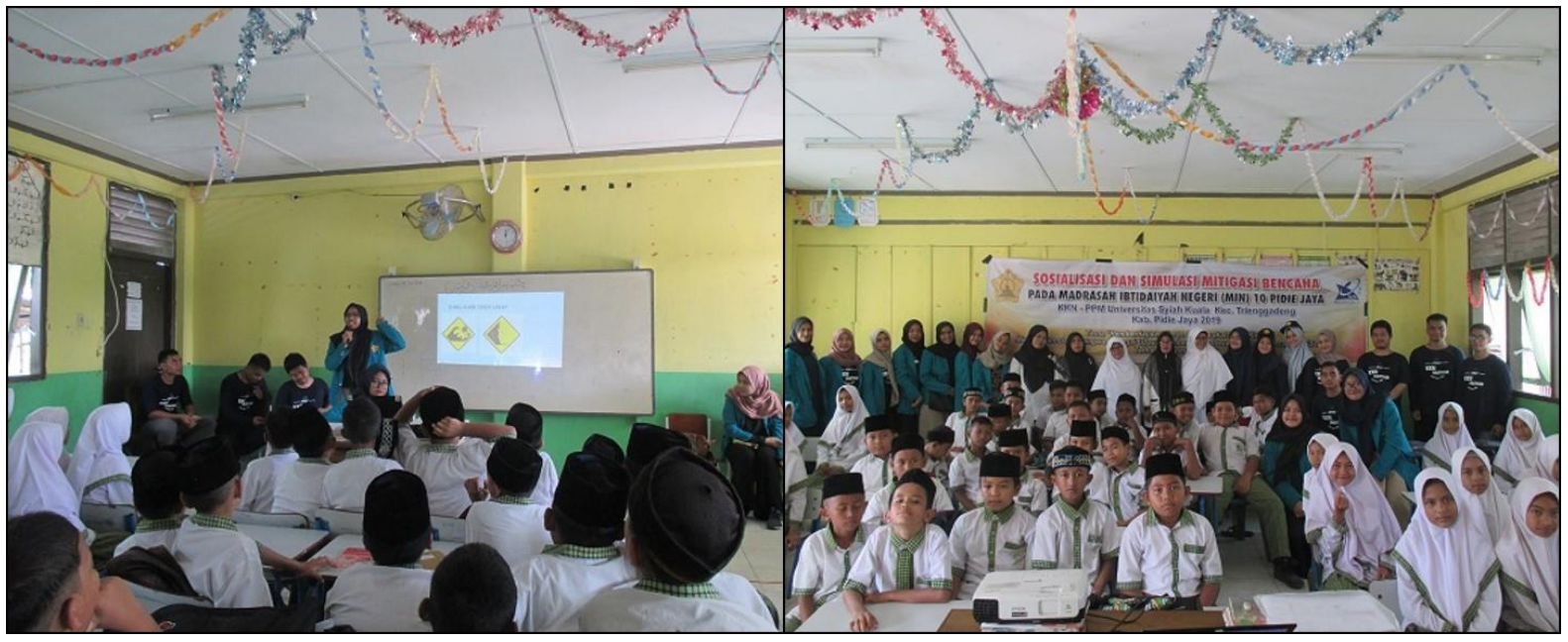

Gambar 3. Melakukan kegiatan Sosialisasi dan Safety Briefing untuk anak sekolah dasar

\section{Pemasangan papan informasi jalur evakuasi}

Pembuatan dan pemasangan papan informasi adalah upaya dari pengurangan risiko bencana pada saat akan terjadi bencana di kemudian hari. Pembuatan papan informasi dilakukan secara bersama-sama dengan pemuda desa setempat. Papan informasi dibuat dalam dua kategori; pertama papan informasi arah jalur evakuasi, dan kedua papan informasi titik berkumpul pada saat terjadi bencana. Penentuan titik pemasangan setiap papan informasi dilakukan berdasarkan kajian secara bersama dengan perangkat dan tokoh masyarakat desa. Hal ini dilakukan sebagai upaya mempertimbangkan nilai kearifan lokal yang ada pada masyarakat tersebut. Selain itu dilakukan analisis dengan menggunakan citra satellite untuk melihat tingkat kemudahan akses pada setiap jalur evakuasi.

Pemasangan papan informasi dilakukan secara bersama antara mahasiswa dan masyarakat (Gambar 4) baik untuk arah jalur evakuasi maupun titik berkumpul. Pemasangan papan informasi arah evakuasi dilakukan pada setiap persimpangan jalan

7 Indarti Komala Dewi et al., "Pembelajaran Pengurangan Risiko Bencana Pada Kurikulum 2013 Untuk Jenjang Pendidikan Dasar," in Prosiding Seminar Nasional IPA-PKLH. Bogor, vol. 22, 2015, $184-191$. 
untuk memberikan informasi jalur yang mudah diakses ke lokasi titik berkumpul, sehingga tidak terjadi kesalahan arah evakuasi yang dapat menambah risiko terjadinya bencana. Titik berkumpul ditentukan berdasarkan pertimbangan beberapa indikator, diantaranya; ${ }^{8}$ (a) ketersedian ruang terbuka yang memadai, (b) Kemudahan akses bagi korban bencana maupun bantuan, (c) cukup aman, tidak langsung berdampak bencana, (d) Ketersedian ruang cukup bagi lansia, (e) Adanya kemudahan akses untuk mobilisasi, (f) Ketersedian akses transportasi yang cukup memadai.

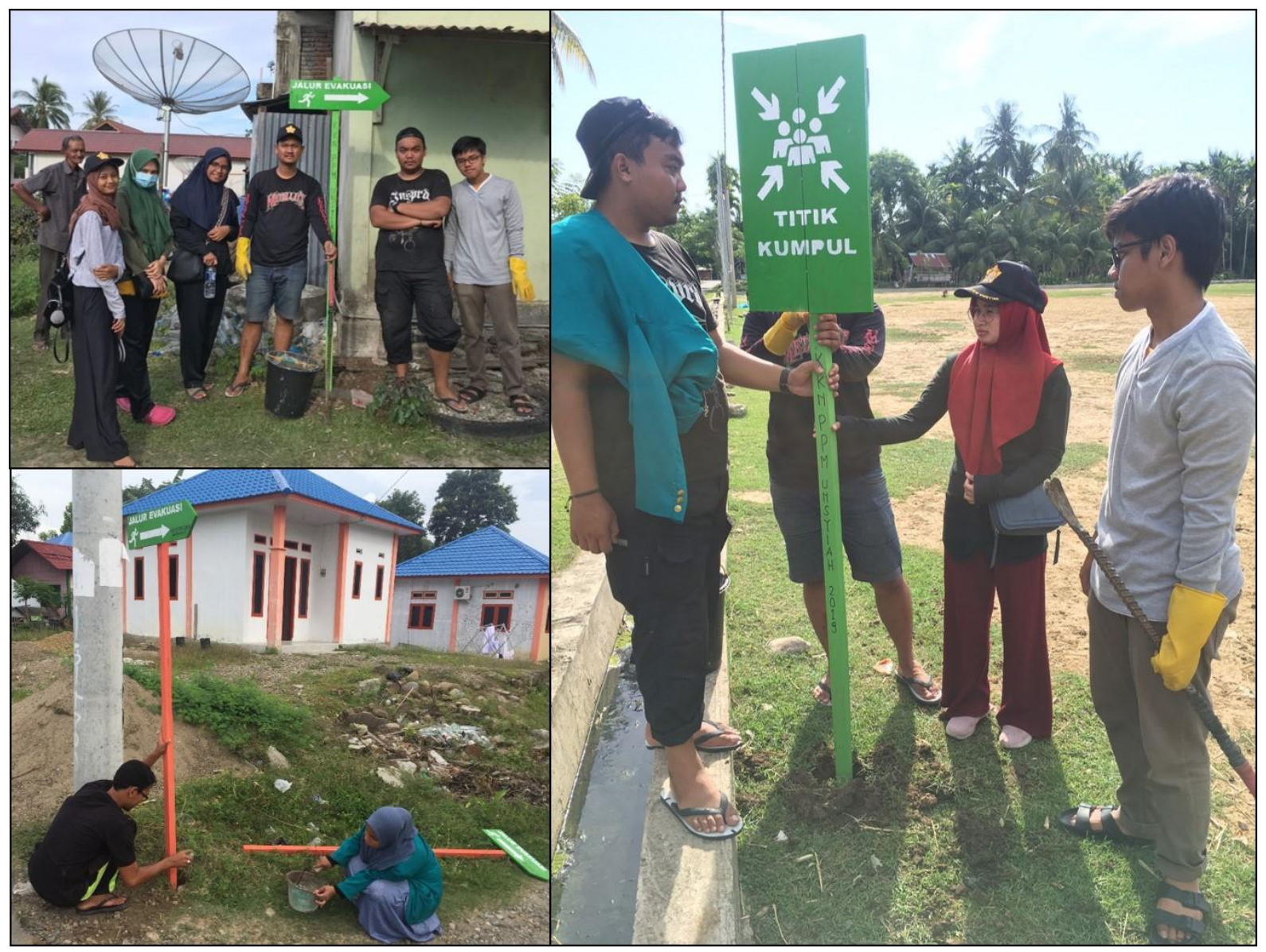

Gambar 4. Pemasangan Jalur Evakuasi Bencana di Desa binaan sebagai upaya pembentukan Desa Tangguh Bencana

\section{Peta Jalu Evakuasi Bencana}

Pembuatan peta jalur evakuasi dilakukan dengan menggunakan Software ArcGIS, program ini adalah salah satu software yang dikembangkan oleh ESRI (Environment Science \& Research Institue) yang merupakan kompilasi fungsi-fungsi dari berbagai macam software GIS yang berbeda seperti GIS desktop, server, dan GIS berbasis web.

${ }^{8}$ Dwi Setyo Mulyatno, "Penentuan Jalur Evakuasi dan Titik Kumpul Terhadap Bencana Gempa Bumi: Studi Kasus di Gedung Pattimura dan Dr. Cipto Mangunkusumo, FTI, UPNVY”. (UPN Veteran Yogyakarta, 2019). 
Untuk lokasi tempat pemasangan papan informasi dilakukan pengambilan titik koordinat dengan menggunakan perangkat Global Positioning System (GPS). Hal ini juga dilakukan untuk informasi infrastruktur desa (fasilitas umum) yang dapat digunakan pada saat terjadi bencana dan batas wilayah dengan desa lain. Sehingga pada saat kegiatan survei mahasiwa di damping secara langsung oleh perangkat desa, untuk memberikan informasi yang akurat.

Peta evakuasi bencana tersebut (Gambar 5), kemudian dicetak dalam ukuran yang besar untuk diletakkan pada beberapa lokasi infrastruktur publik seperti Meunasah (Surau), Kantor Keuchik, sekolah dan beberapa tempat infrastruktur lainnya. Sehingga akan menjadi media pembelajatan bagi masyarakat terkait potensi dan mitigasi bencana di desa tersebut. Penyerahan peta dilakukan secara simbolis pada kegiatan pelantikan tim satgas bencana yang ikut disaksikan oleh Camat Tringgadeng.

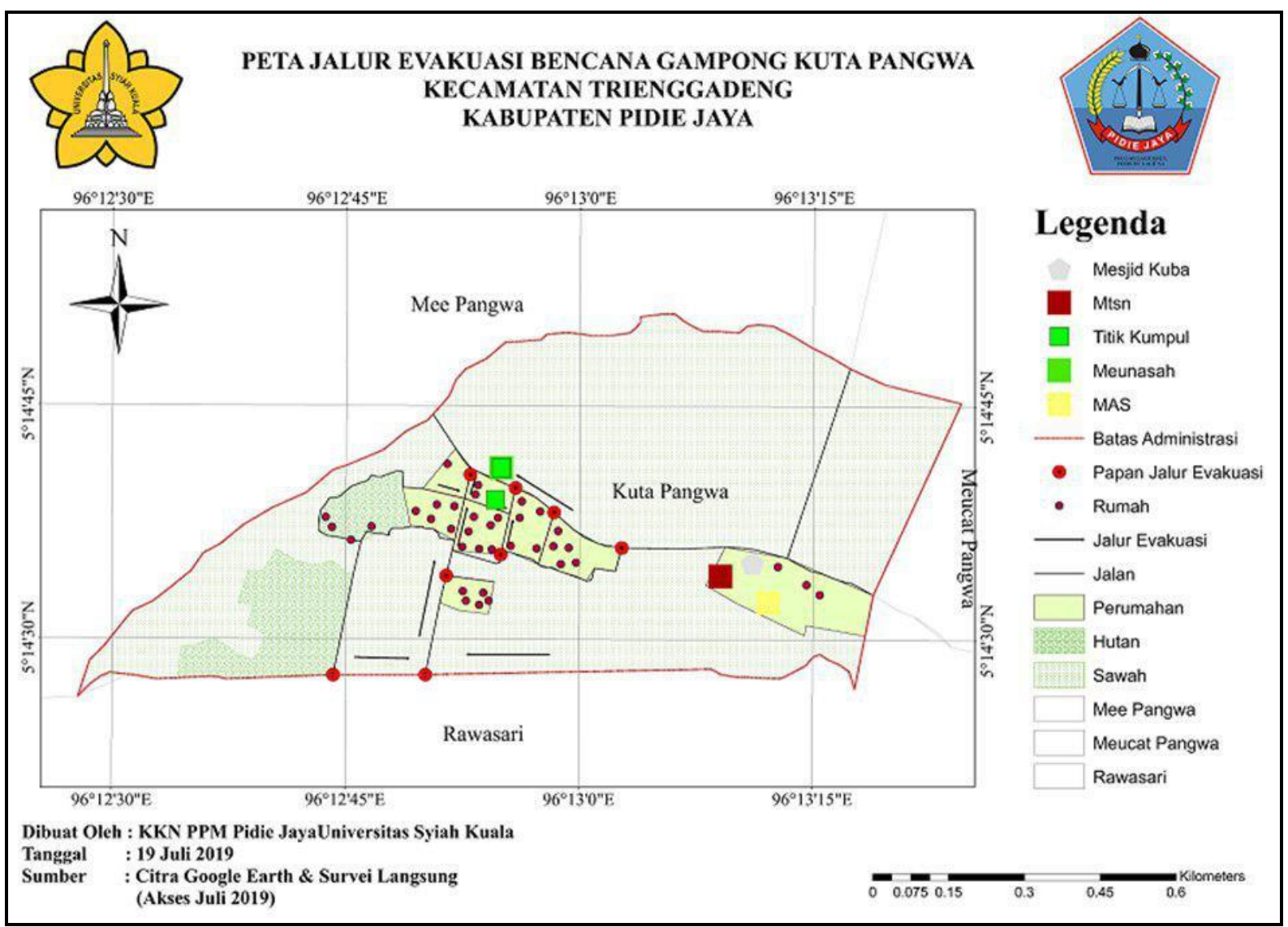

Gambar 5. Peta jalur evakuasi bencana pada desa Meucat Pangwa

\section{Pembentukan Tim Sigap Bencana yang tertuang dalam Peraturan Desa}

Pembentukan Desa Tangguh Bencana memiliki elemen penting berupa tim Pengurangan Risiko Bencan (PRB) sebagai penggerak kegiatan mitigasi bencana di tingkat pemerintahan desa. Tim PRB merupakan lembaga yang memiliki legalitas sebagai penggerak mitigasi bencana di bawah naungan pemerintahan desa. Hal ini 
tertuang dalam peraturan desa berbasis mitigasi bencana yang dirumuskan secara bersama dengan melibatkan pemerintah desa, masyarakat desa, muspika kecamatan, Badan Penanggulanga Bencana Daerah, dan pakar kebencanaan dari Universitas Syiah Kuala. Legalitas lembaga PRB adalah hal penting untuk menjamin keberlanjutan program DESTANA setelah kegiatan berlangsung, selain itu untuk dapat mengatur sistem penggunaan anggaran sebagai operasional program PRB di tingkat desa. Namun hal paling utama dari legalitas adalah dapat meningkatkan partisipasi masyarakat dalam kegiatan pengurangan risiko bencana sebagai upaya mengoptimalkan peran aktif masyarakat.

Proses perekrutan dilakukan dengan diskusikan secara langsung kepada perangkat desa melalui pelibatan pihak pemuda secara dominan. Tim ini terdiri dari 3 bagian yaitu dapur umum, tanggap darurat dan tim edukasi bencana kepada masyarakat. Dapur umum bertugas sebagai pihak yang akan melakukan persiapan terkait pembuatan makanan, bidang tanggap darurat bertugas sebagai yang memberikan arahan terkait penanggulan bencana. Sedangkan tim edukasi bencana bertugas untuk memberikan sosialisasi tentang mitigasi bencana gempa bumi. Semua tim yang sudah direkrut diberikan pembekalan mengenai mitigasi bencana dan tanggung jawab mereka dalam kegiatan pengurangan risiko bencana di Kantor Camat Trienggadeng (Gambar 6). Tim PRB juga mendapatkan pembekalan mengenai bagaimana menganalisis potensi bencana yang ada disekitar dan upaya mitigas bencana sebelum, saat, dan sesudah bencana.

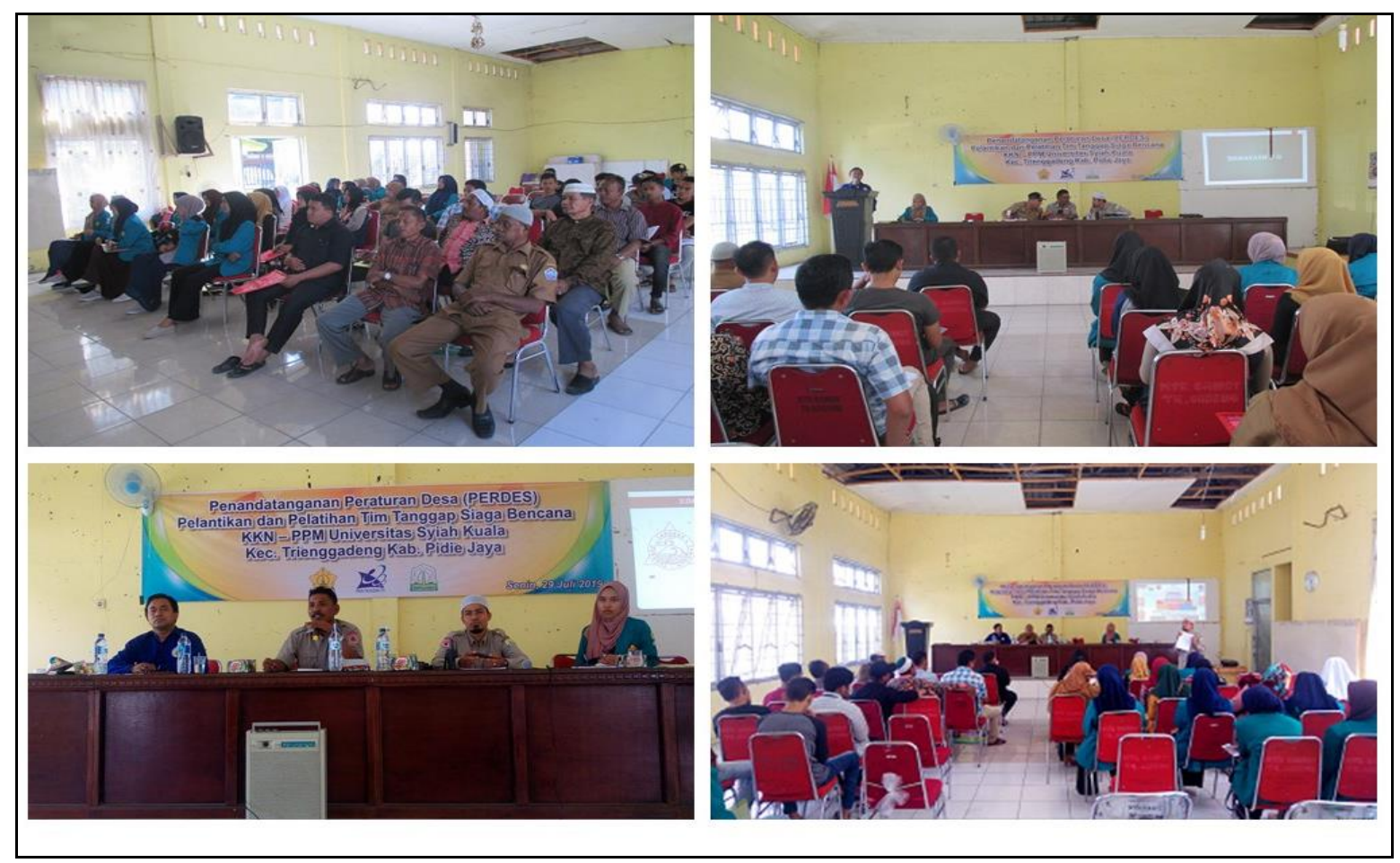

Gambar 6. Pelantikan dan pembekelan Tim Pengurang Risiko Bencana Tingkat Desa. 


\section{Pengetahuan Masyarakat tentang Kebencanaan}

Studi tingkat pengetahuan masyarakat terhadap mitigasi bencana gempa bumi dilakukan sebagai upaya mengukur sejauhmana tingkat keberhasilan program Desa Tangguh Bencana mampu meningkatkan pengetahuan bencana gempa bumi bagi masyarakat. Kegiatan ini dilakukan pada saat Focus Group Discussion (FGD) tentang pembembentukan DESTANA kepada masyarakat.

Pada saat sebelum dan sesudah kegiatan diberikan kuisioner kepada masyarakat untuk melihat sejauh mana pengetahuan dasar dan peningkatan pengetahuan masyarakat terhadap mitigasi bencana gempa bumi. Quisioner ini diberikan kepada 35 orang masyarakat yang terdiri dari 11 orang lelaki dan 24 orang perempuan. Beberapa pertanyaan yang diberikan kepada masyarakat meliputi pengetahuan umum kebencanaan dan sikap yang dilakukan ketika terjadi bencana. Adapun hasil evaluasi melalui angket ini dapat diuraikan sebagai berikut.

\section{Pertama, pengetahuan masyarakat terkait "bencana alam."}

Berdasarkan Gambar 7. Menunjukkan hasil studi yang dilakukan untuk melihat pengetahuan masyarakat terkait "bencana alam", dimana secara umum terjadi perubahan signifikan terhadap pengetahuan masyarakat sebelum dan sesudah kegiatan FGD dilakukan. Perubahan yang paling signifikan dapat dilihat pada opsi jawaban"yang diakibatkan oleh bencana alam", dimana sebelum FGD memiliki 54.29\% responden. Namun setelah kegiatan FGD hanya $22.71 \%$ responden dari seluruh peserta. Hal ini menunjukkan adanya perubahan pengetahuan masyarakat terhadap kebencanaan.

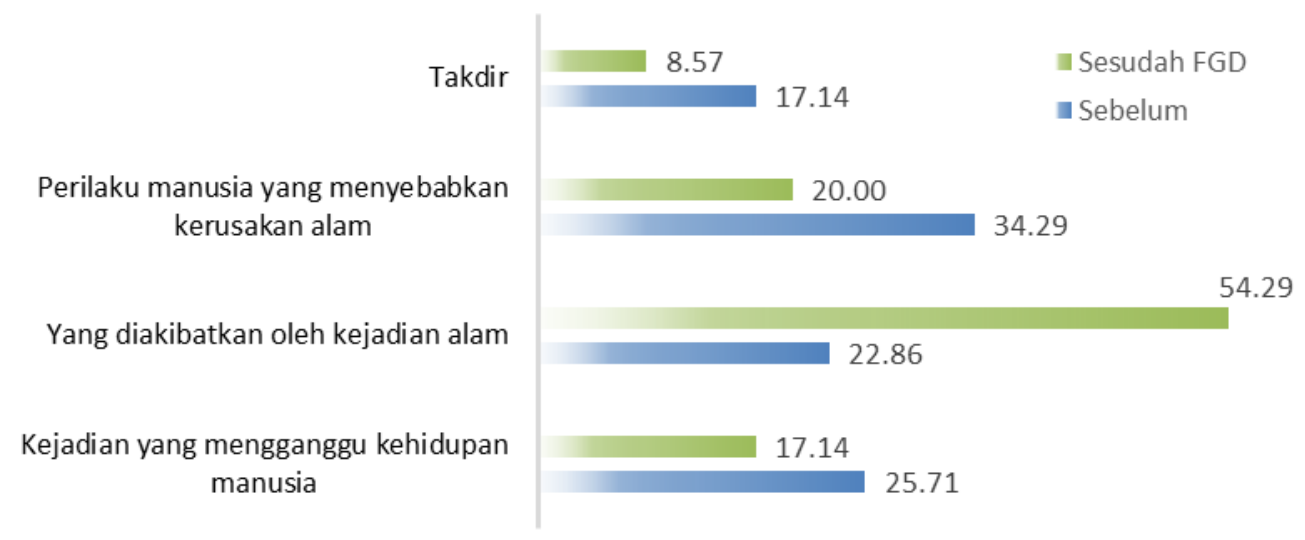

Gambar 7. Respon pengetahuan masyarakat terkait bencana alam

\section{Kedua, pengetahuan terkait sebab terjadinya bencana gempa bumi}

Hasil dari pertanyaan ini menunjukkan (Gambar 8) sebelum dilaksanakan FGD ada $45 \%$ masyarakat yang menjawab bahwa bencana gempa bumi disebabkan oleh pergerakan kerak bumi, namun setelah FGD ada 80\% masyarakat menjawab hal yang 
serupa. Peningkatan tingkat pengetahuan ini disebabkan oleh materi tentang kebencanaan yang telah diberikan secara komprehensif.

Selain itu terdapat $25.71 \%$ masyarakat menjawab bahwa meletusnya gunung api juga dapat menyebabkan gempa bumi, namun gempa bumi ini tidak dapat dirasakan oleh manusia, karena intensitas magnitude dibawah 5 S.R.

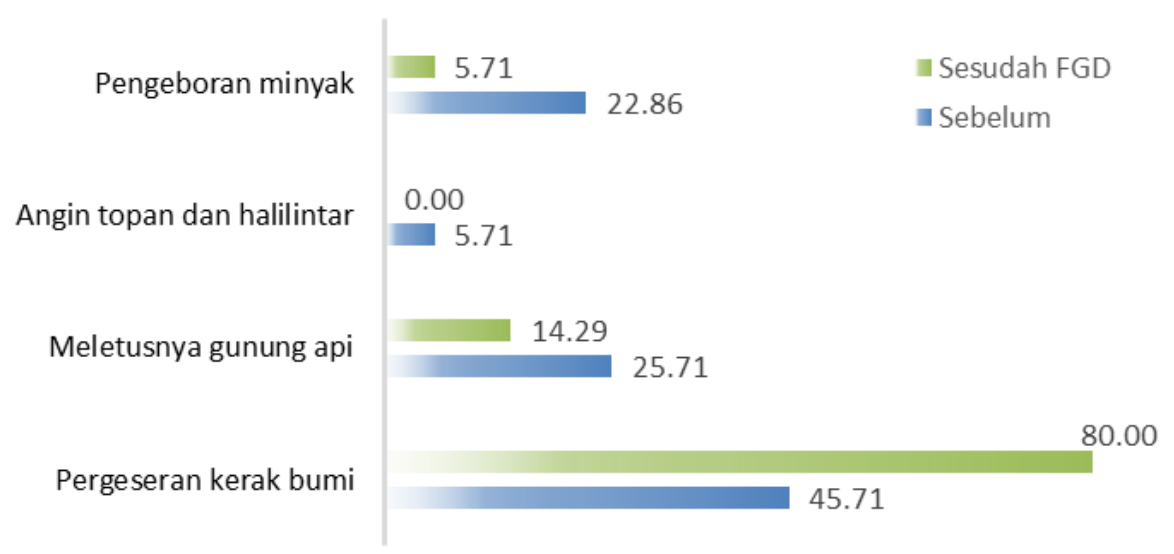

Gambar 8. Respon pengetahuan penyebab terjadi bencana gempa bumi

Hasil yang diperoleh dari studi ini (Gambar 9) menunjukkan 48.57\% masyarakat menjawab bahwa tsunami merupakan jenis bencana lain yang dapat timbul akibat adanya gempa bumi, sedangkan setelah dilaksanakan FGD, maka terjadi kenaikan yaitu $85.71 \%$ masyarakat menjawab tsunami, begitu juga untuk gunung meletus yang sebelumnya ada $22.86 \%$ kemudian setelah FGD berkurang menjadi $11.43 \%$.

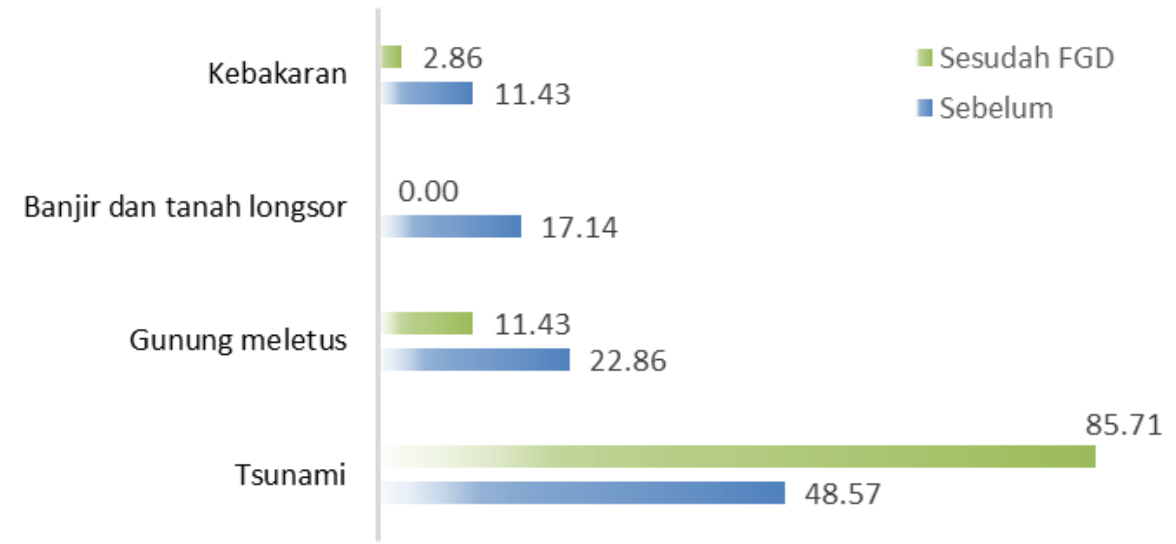

Gambar 9. Apakah Jenis Bencana lain yang dapat ditimbulkan oleh gempa bumi 


\section{Ketiga, Pengetahuan tentang tindakan masyarakat saat terjadi gempa bumi}

Sedangkan untuk hasil studi terakhir terkait repon yang dilakukan pada saat terjadi bencana diperoleh hasil yang beragam, namun sebagian koresponden tidak dapat memberikan jawaban terkait apa yang harus dilakukan pada saat terjadi bencana, hal ini disebabkan oleh pilihan jawaban yang tersedia menjadikan responden ragu untuk menentukan pilihan yang lebih tepat. Hasil studi yang dilakukan pada saat sebelum dan sesudah FGD (Gambar 10, 11, 12, 13, dan 14) menunjukkan perubahan yang sangat signifikan.

Pada Gambar 10, menunjukkan hasil studi yang dilakukan terhadap respon yang diberikan pada saat terjadi bencana gempa bumi. Hasil tersebut menunjukkan adanya perubahan pilihan responden sebelum dan sesudah kegiatan FGD dilakukan. Hasil sebelum dilakukan FGD hanya sebanyak $97.14 \%$ menyatakan akan lari dan menyelamatkan diri pada saat terjadi bencana gempa bumi, sedangkan sisanya $2.86 \%$ akan memilih tetap berada dalam rumah atau bangunan. Namun setelah FGD sebanyak 100 responden menyatakan akan lari untuk menyelamatkan diri.

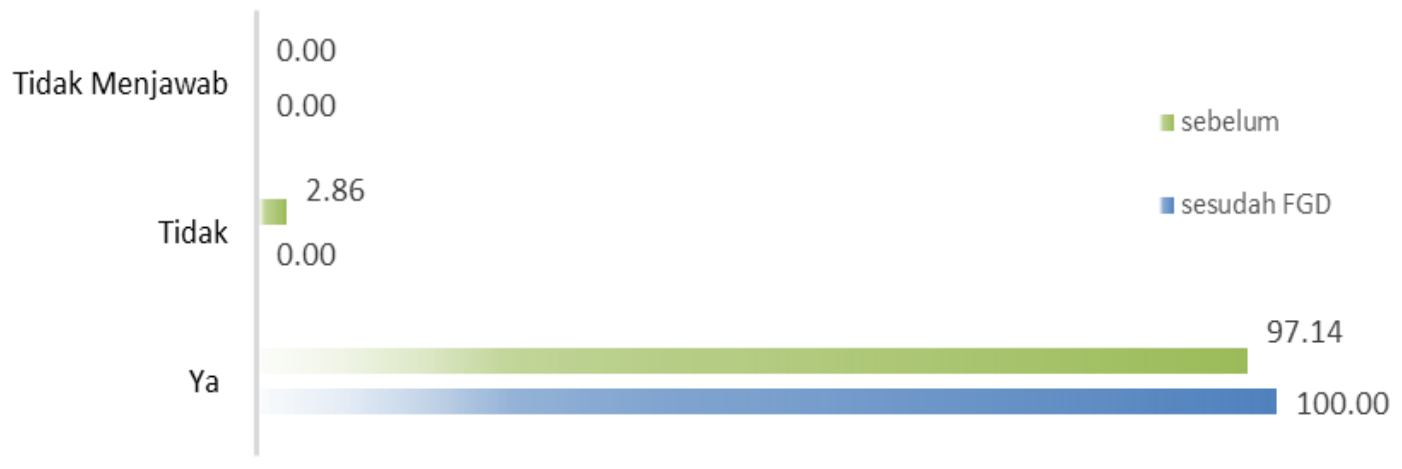

Gambar 10. Akan lari dan menyelamatkan diri.

Gambar 11, menunjukkan hasil studi yang dilakukan terhadap respon masyarakat pada saat terjadi bencana gempa bumi dengan pilihan jawaban menenangkan anggota keluarga dan masyarakat disekitarnya. Berdasarkan hasil yang didapatkan terlihat adanya peningkatan respon masyarakat untuk menenangkan anggota keluarga dan masyarakat disekitarnya. Pada saat sebelum dilakukan FGD sebanyak $88.57 \%$ menyatakan iya dan $2.86 \%$ menyatakan tidak, sisanya tidak memberikan jawaban. Sedangkan setelah dilakukan FGD ada perubahan data yang sangat signifikan, dimana jumlah reponden yang menyatakan ia meningkat menjadi 97.14\% dan 2.86\% tidak memberikan jawaban. 


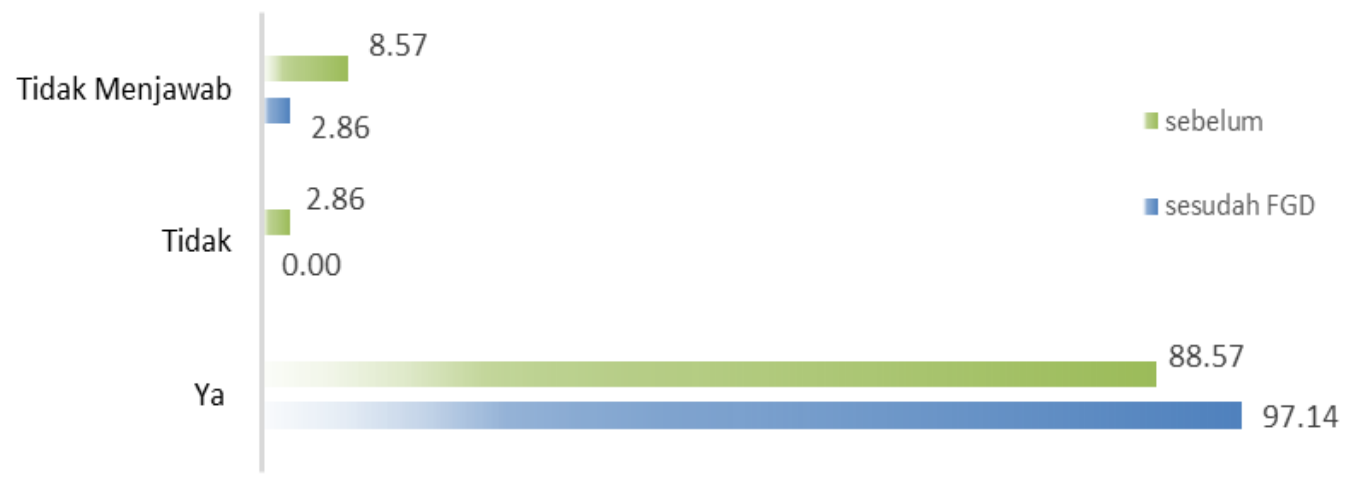

Gambar 11. Menenangkan anggota keluarga dan masyarakat disekitar.

Gambar 12, menunjukkan hasil studi yang dilakukan dengan memberikan opsi pilihan jawaban berupa "memberikan aba-aba agar masyarakat yang lainnya berlindung ditempat aman atau bawah meja", dimana respon masyarakat secara umum menunjukkan peningkatan yang signifikan dengan jawaban ya. Pada studi sebelum FGD hanya $65.71 \%$ yang menyatakan iya dan sisa $34.29 \%$ tidak memberikan jawaban. Sedangkan hasil studi setelah survei menunjukkan peningkatan menjadi $94.29 \%$ dengan jawaban ya dan sisa $5.71 \%$ tidak memberikan jawaban.

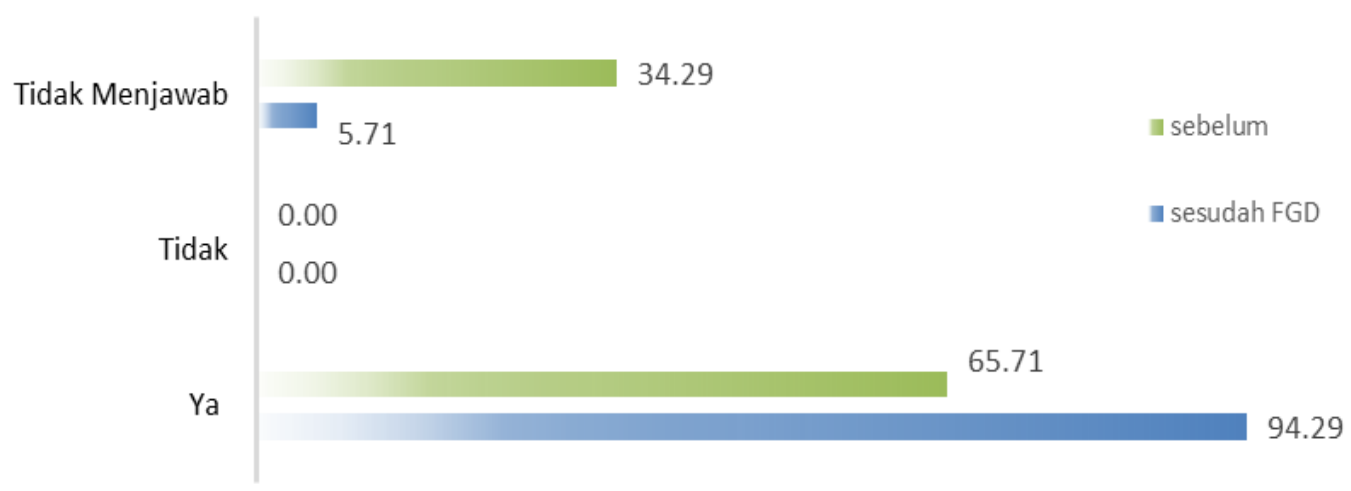

Gambar 12. Memberi aba-aba agar masyarakat desa berlindung di bawah meja yang kokoh sampai getaran gempa bumi berhenti.

Hasil studi yang dilakukan dengan opsi jawaban memandu anggota keluarga dan masyarakat untuk berlindung ditempat yang aman pada saat terjadi bencana menunjukkan (Gambar 13) perubahan yang sangat besar setelah dan sesudah dilakukan kegiatan FGD. Data tersebut menunjukkan hasil yang kurang memuaskan, dimana hanya $42.86 \%$ yang menyatakan iya, sedangkan $22.86 \%$ menyatakan tidak dan sisanya sebesar $34.29 \%$ tidak memberikan jawaban. Sedangkan pada saat setelah dilakukan FGD adanya peningkatan yang besar, dimana $88.57 \%$ menyatakan iya dan $11.43 \%$ menyatakan tidak. 


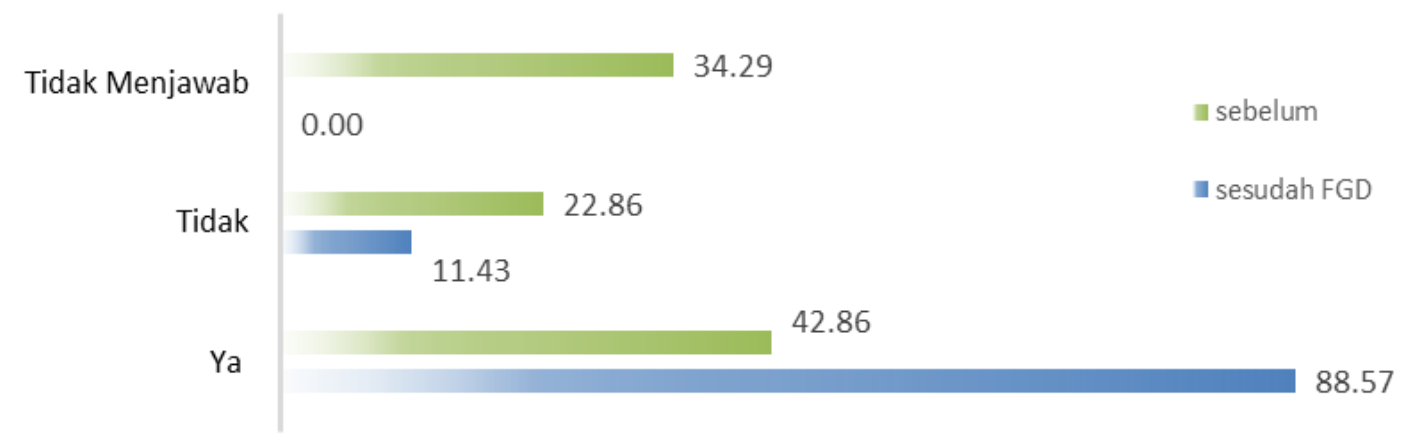

Gambar 13. Memandu anggota keluarga/masyarakat desa merunduk kearah pintu sambil melindungi kepala.

Hasil studi dengan opsi pilihan memandu masyarakat desa untuk menuju tempat pengungsian/evakuasi menunjukkan (Gambar 14) perbedaan respon yang sangat besar setelah dan sesudah dilakukan FGD. Pada hasil studi sebelum sebanyak 42.86\% responden memilih iya dan $22.86 \%$ memilih tidak, sedangkan sisanya tidak memberikan jawaban. Untuk data yang dilakukan setelah menunjukkan peningkatan menjadi $88.57 \%$ memilih iya dan sisianya $11.43 \%$ memilih tidak.

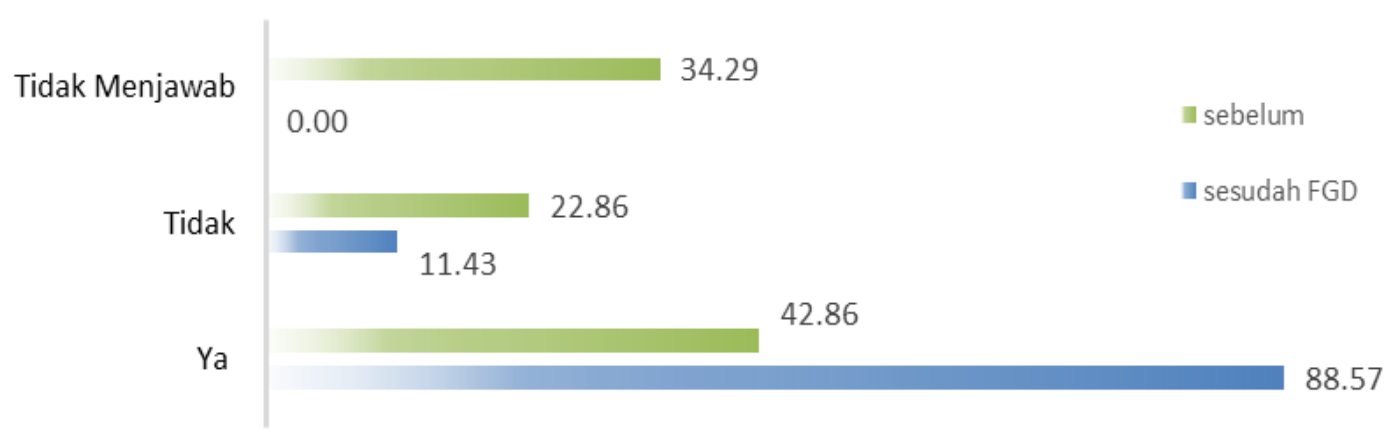

Gambar 14. Memandu masyarakat desa untuk menuju tempat pengungsian/evakuasi (tempat berkumpul).

Hasil studi pengetahuan masyarakat menunjukkan bahwa respon masyarakat sebagian besar persentase koresponden memiliki pengetahuan mitigasi bencana yang kurang dan memiliki respon yang kurang sigap pada saat terjadi bencana gempa bumi. Hasil setelah FGD menunujukkan peningkatan persentase yang menyatakan iya. Sehingga hasil secara umum dapat dikatakan bahwa kegiatan sosialisasi dan FGD yang dilakukan berhasil meningkatkan pengetahuan masyarakat terhadap kegiatan pengurangan risiko bencana. 


\section{Kesimpulan}

Pembentukan Desa Tangguh Bencana di kawasan Kecamatan Trienggadeng, Kabupaten Pidie Jaya merupakan kebutuhan yang sangat mendesak, hal ini dikarenakan daerah tersebut memiliki potensi bencana gempa bumi yang sangat besar. Pembentukan DESTANA adalah upaya yang mampu membentuk masyarakat yang sigap akan bencana. Mengoptimalkan peran aktif masyarakat merupakan suatu keharusan untuk mendorong terciptanya program berkelanjutan di masa yang akan datang.

Implementasi penerapan perdes yang berbasis pada pengurangan risiko bencana gempa bumi dilakukan secara bersama dengan melibatkan muspika tingkat kecematan dan Badan Penanggulangan Bencana Daerah Pidie Jaya untuk memastikan bahwa desa tersebut dapat mengimplementasikan Perdes dengan baik. Selain itu sangat diharapkan untuk dapat menjadi percontohan bagi desa yang lain disekitarnya. Dari kegiatan yang telah berlangsun dapat dilihat bahwa selama ini masyarakat di daerah yang rawan bencana sangat mengharapkan peran aktif dari semua pihak untuk meningkatkan pemahaman mereka akan mitigasi bencana.

Pemberdayaan masyarakat terhadap mitigasi bencana juga sangat perlu dilakukan terhadap anak-anak usia dini sebagai upaya membentuk regenerasi yang siap untuk hidup secara berdampingan dengan potensi bencana gempa bumi yang ada disekitarnya. Pembelajaran tersebut dapat dilakukan dengan pendekatan yang lebih menarik minat siswa, berupa game dan modul kebencanaan dalam bentuk kartun. Selain itu dapat dilakukan dengan pemutaran film kartun safety briefing yang menarik, sehingga akan menambah minat para anak-anak untuk memahami mitigasi bencana.

\section{Daftar Referensi}

Dewi, Indarti Komala, Elly Sukmanasa, Griet Helena Laihad, and PGSD-FKIP Prodi. "Pembelajaran Pengurangan Risiko Bencana Pada Kurikulum 2013 Untuk Jenjang Pendidikan Dasar." In Prosiding Seminar Nasional IPA-PKLH. Bogor, 22:184-191, 2015.

Genrich, J F, Y Bock, R McCaffrey, L Prawirodirdjo, C W Stevens, S S O Puntodewo, C Subarya, and Shimon Wdowinski. "Distribution of Slip at the Northern Sumatran Fault System." Journal of Geophysical Research: Solid Earth 105, no. B12 (2000): 28327-28341.

Ito, Takeo, Endra Gunawan, Fumiaki Kimata, Takao Tabei, Mark Simons, Irwan Meilano, Yusaku Ohta, Irwandi Nurdin, and Didik Sugiyanto. "Isolating Along-strike Variations in the Depth Extent of Shallow Creep and Fault Locking on the Northern Great Sumatran Fault." Journal of Geophysical Research: Solid Earth 117, no. B6 (2012). 
Kartika, Siska Ayu, Agung Prabasworo, and Abdy Nugroho. "Sosialisasi Upaya Pencegahan Dan Penanggulangan Bahaya Kebakaran Di Sekolah Luar Biasa (SLB) Kota Balikpapan." Abdimas Universal 1, no. 2 (2019): 30-38.

Mulyatno, Dwi Setyo. "Penentuan Jalur Evakuasi dan Titik Kumpul terhadap Bencana Gempa Bumi: Studi Kasus Di Gedung Pattimura Dan Dr. Cipto Mangunkusumo, FTI, UPNVY." UPN Veteran Yogyakarta, 2019.

Oktari, Rina Suryani. "Peningkatan Kapasitas Desa Tangguh Bencana." Jurnal Pengabdian kepada Masyarakat (Indonesian Journal of Community Engagement) 4, no. 2 (2019): 189-197.

Putra, I Wayan Krisna Eka, and I Putu Gede Diatmika. "Rintisan Desa Tangguh Bencana (Destana) Di Desa Gitgit, Kecamatan Sukasada, Kabupaten Buleleng." Jurnal Ilmiah Ilmu Sosial 4, no. 2 (2018): 161-166.

Sieh, Kerry, and Danny Natawidjaja. "Neotectonics of the Sumatran Fault, Indonesia." Journal of Geophysical Research: Solid Earth 105, no. B12 (2000): 28295-28326. 